GRASAS Y ACEITES 67 (4)

October-December 2016, e166

ISSN-L: 0017-3495

doi: http://dx.doi.org/10.3989/gya.0559161

\title{
Study of volatile alcohols and esters from the subcutaneous fat during ripening of Iberian dry-cured ham. A tool for predicting the dry-curing time
}

\author{
M. Narváez-Rivas, E. Gallardo and M. León-Camacho ${ }^{\varpi}$ \\ Food Characterization and Quality Department, Instituto de la Grasa (C.S.I.C.) \\ Ctra. Utrera km 1, Campus Universitario Pablo de Olavide, 41013 Seville-Spain \\ ${ }^{\square}$ Corresponding author: mleon@cica.es
}

Submitted: 06 May 2016; Accepted: 11 July 2016

\begin{abstract}
SUMMARY: Variations in the amounts of volatile alcohols and esters from subcutaneous fat have been assessed during the dry-curing process (1022 days) of Iberian ham according to a purge and trap-gas chromatography-mass spectroscopy method, using the same hams throughout the process. During processing time, the subcutaneous adipose tissues of ten hams obtained from five Iberian pigs fed on acorns and pasture were sampled and analyzed once per month. Fifteen alcohols and five esters have been identified. All volatile alcohols detected in this work have been previously identified by other authors on Iberian ham, except 3-buten-2-ol, 5-methyl-3-hexanol and 2-isononanol. A linear discriminant analysis (LDA) was applied and the two discriminant functions were obtained using backward stepwise analysis retaining the following variables: butyl ester formic acid, 1-penten-3-ol, methyl ester 2-propenoic acid, 5-methyl-3-hexanol, 1-nonanol, ethyl ester pentanoic acid, ethyl ester hexanoic acid, 2-isononanol, ethanol and 3-buten-2-ol. A complete separation among the three periods was obtained, suggesting that the retained variables are powerful descriptors to distinguish samples from these three dry-curing stages.
\end{abstract}

KEYWORDS: Iberian ham; Patter recognitions; Purge and Trap; Ripening; Volatile alcohols; Volatile esters

RESUMEN: Estudio de los alcoholes y ésteres volátiles de la grasa subcutánea durante la maduración del jamón ibérico. Una herramienta para predecir el tiempo de curación. Se han evaluado durante el proceso de curación (1022 días), las variaciones en los contenidos de alcoholes y ésteres volátiles de la grasa subcutánea del jamón ibérico mediante la técnica de acoplamiento purga y trampa- cromatografía de gases-espectrometría de masas, utilizando los mismos jamones a lo largo de todo el proceso. Durante el tiempo de curación se muestreó y analizó una vez al mes el tejido adiposo subcutáneo de diez jamones procedente de cinco cerdos ibéricos alimentados con bellotas y pastos. Se han identificado quince alcoholes y cinco ésteres volátiles. Todos los alcoholes descritos en este trabajo han sido identificados previamente por otros autores en el jamón ibérico, excepto el 3-buten-2-ol, el 5-metil-3-hexanol y el 2-isononanol. Un análisis lineal discriminante por pasos (LDA) fue aplicado y se obtuvieron dos funciones discriminantes las variables incluidas en el modelo fueron: formiato de butilo, 1-penten-3-ol, 2-propenoato de metilo, 5-metil-3- hexanol, 1-nonanol, pentanoato de etilo, hexanoato de etilo, 2-isononanol, etanol y 3-buten-2-ol. Obteniéndose una completa separación entre los tres períodos, lo que sugiere que las variables indicadas son poderosos descriptores para distinguir entre las tres etapas de curación.

PALABRAS CLAVE: Alcoholes volátiles; Ésteres volátiles; Jamón ibérico; Maduración; Purga y trampa; Reconocimiento de patrones

Citation/Cómo citar este artículo: Narváez-Rivas M, Gallardo E, León-Camacho M. 2016. Study of volatile alcohols and esters from the subcutaneous fat during ripening of Iberian dry-cured ham. A tool for predicting the dry-curing time. Grasas Aceites 67, e166. http://dx.doi.org/10.3989/gya.0559161.

Copyright: ( 2016 CSIC. This is an open-access article distributed under the terms of the Creative Commons Attribution (CC-by) Spain 3.0 License. 


\section{INTRODUCTION}

Due to the traditional techniques used for manufacturing and because the pigs are raised in freerange conditions, the Iberian dry-cured ham is characterized by a flavor with strong intensity. The production area of Iberian pigs constitute the southwest of Spain and the south of Portugal, providing an international importance to the products derived from this and as consequence to the dry-cured ham. Their artisanal production method has lasted due to its highly demanded characteristics (Andersen et al., 2005). The elaboration of the Iberian dry-cured ham is a long traditional process of ripening (about 2-3 years), where the understanding of it could help to improve the product quality and optimize the duration of processing. The definition of analytical parameters could help to attest the quality and typical traits of the Iberian dry-cured ham. It has been demonstrated that the sensory quality (aroma, flavor and texture) of this product derived from Iberian pig depends on ripening conditions (Andrés et al., 2007; Flores et al., 1997; Ruiz et al., 1999) and factors that affect the raw meat characteristics, such as the rearing system, mainly during the fattening period, the age of the animals and pig genotype (Dirinck et al., 1997; Jurado et al., 2007; NarváezRivas et al., 2010b, 2011; Ramírez and Cava, 2007; Sabio et al., 1998).

Due to the importance of the flavor in hams, previous works can be found in the literature studying the generation of volatile compounds in Iberian (Narváez-Rivas et al., 2014, 2015), Serrano (Pérez-Juan et al., 2006), Celta (Lorenzo et al., 2013, Bermúdez et al., 2015), Parma (Hinrichsen and Pedersen, 1995; Bolzoni et al., 1996) and Chinese Jinhua (Huan et al., 2005) hams. The drycuring process of hams is a complex process where reactions of hydrolysis and oxidation take place and produce the degradation of the lipid fraction from the adipose tissue (Coutron-Gambotti and Gandemer, 1999). On one hand, triacylglycerols and diacylglycerols and to a lesser extent monoacylglycerols and phospholipids (Narváez-Rivas et al., 2007, 2008, 2013) are mainly affected by the reactions of hydrolysis. The drying period is where an intense lipolysis of triacylglycerols and diacylglycerols can be observed. The hydrolysis would be more influenced by enzymes and microorganism action during post-salting and drying periods, while cellar would be characterized by chemical hydrolysis of acylglycerols, oxidation of these and fatty acids and sweating of the fat (Narváez-Rivas et al., 2013). The oxidation reactions that take place during the process affect the fatty acids, producing oxidized compounds that have a short life and some volatiles are responsible for the characteristic flavor of dry-cured ham (Antequera et al., 1992).
Many factors can affect the production of volatile compounds in dry-cured hams. The volatile compounds ( 7 and 12 months) can be affected by the chemical composition of different dry-cured Serrano ham sections (shank, center, butt). For example, the center section had the highest proportion of volatiles due not only to the higher concentration of free amino acids but also to the oxidation of unsaturated fatty acids (Pérez-Juan et al., 2006). The influence of processing conditions like relative humidity and temperature can affect the evolution of volatile aldehydes in Iberian hams (Martín et al., 2000). Temperature had a marked influence on their formation, especially during post-salting and drying, which could influence the sensory characteristics of the final products. Supplementation with $\alpha$-tocopheryl and the extensive feeding (free-range reared on acorn and pasture) of pigs also had an effect on these compounds during the maturation of Iberian ham (Cava et al., 1999).

In this work, changes in volatile alcohols and esters from subcutaneous fat were studied during the dry-curing process of Iberian ham. The understanding of this processing could help to improve product quality and optimize the duration of the process. Moreover, the identified volatile compounds have been used as chemical descriptors to discriminate the three dry-curing periods, which can be useful to develop hams with comparable quality. In relation to this purpose, several pattern recognition techniques have been applied. Principal component analysis (PCA) was applied to visualize possible data tendencies in the sample distribution as well as the discriminant power of the variables and linear discriminant analysis (LDA) was used to build a suitable classification model and reduce the number of input variables. The present work is a continuation of previous studies about the dry-curing process of Iberian ham (Narváez-Rivas et al., 2013a, 2013b, 2014, 2015).

\section{MATERIAL AND METHODS}

\subsection{Chemicals and reagents}

The standards shown in Table 1 and isoamyl butyrate were obtained from Sigma Aldrich Fluka (Steinheim, Germany). Standard solutions were prepared using fully deodorized edible oil as matrix. Concentrations were in the range of $0.1-$ $5.0 \mathrm{mg} \cdot \mathrm{kg}^{-1}$.

\subsection{Processing of hams and sampling}

Ten hams (between 10.80 and $12.83 \mathrm{~kg}$, mean of $11.69 \mathrm{~kg}$ ) from the designated origin of "Los Pedroches" were obtained from five castrated Iberian pure 14-month-old pig males, fattened extensively with acorns and pastured for 90 days 
TABLE 1. Volatile alcohols and esters identified in subcutaneous fat from Iberian ham (see Fig. 1)

\begin{tabular}{|c|c|c|c|c|c|}
\hline Peak & Volatile compounds & Identification & $T_{R R}$ & Base peak & $\mathbf{M}^{+}$ \\
\hline 1 & 2-propenyl ester acetic acid & $\mathrm{S} / \mathrm{L}$ & 0.112 & 43 & 101 \\
\hline 2 & ethanol & $\mathrm{S} / \mathrm{L}$ & 0.119 & 31 & 46 \\
\hline 3 & 2-propanol & $\mathrm{S} / \mathrm{L}$ & 0.166 & 45 & 59 \\
\hline 4 & 1-methoxy-2-propanol & $\mathrm{S} / \mathrm{L}$ & 0.169 & 45 & 90 \\
\hline 5 & methyl ester 2-propenoic acid & $\mathrm{L}$ & 0.231 & 55 & 87 \\
\hline 6 & 3-buten-2-ol & $\mathrm{S} / \mathrm{L}$ & 0.326 & 57 & 73 \\
\hline 7 & 2-methyl-2-pentanol & $\mathrm{S} / \mathrm{L}$ & 0.398 & 59 & 88 \\
\hline 8 & 5-methyl-3-hexanol & $\mathrm{S} / \mathrm{L}$ & 0.412 & 59 & 99 \\
\hline 9 & 3-methyl-3-pentanol & $\mathrm{S} / \mathrm{L}$ & 0.458 & 73 & 103 \\
\hline 10 & ethyl ester pentanoic acid & $\mathrm{L}$ & 0.519 & 29 & 131 \\
\hline 11 & butyl ester formic acid & $\mathrm{S} / \mathrm{L}$ & 0.565 & 56 & 102 \\
\hline 12 & 1-penten-3-ol & $\mathrm{S} / \mathrm{L}$ & 0.606 & 57 & 87 \\
\hline 13 & ethyl ester hexanoic acid & $\mathrm{L}$ & 0.869 & 88 & 145 \\
\hline 14 & 1-pentanol & $\mathrm{S} / \mathrm{L}$ & 0.956 & 42 & 88 \\
\hline 15 & 1-hexanol & $\mathrm{S} / \mathrm{L}$ & 1.394 & 56 & 102 \\
\hline 16 & 2-isononanol & $\mathrm{L}$ & 1.575 & 43 & 140 \\
\hline 17 & 1-octen-3-ol & $\mathrm{S} / \mathrm{L}$ & 1.818 & 57 & 129 \\
\hline 18 & 1-heptanol & $\mathrm{S} / \mathrm{L}$ & 1.830 & 70 & 99 \\
\hline 19 & 1-octanol & $\mathrm{S} / \mathrm{L}$ & 2.214 & 41 & 113 \\
\hline 20 & 1-nonanol & $\mathrm{S} / \mathrm{L}$ & 2.249 & 56 & 127 \\
\hline
\end{tabular}

L: Library; S: Standard; $\mathrm{T}_{\mathrm{RR}}$ : relative retention time; $\mathrm{M}^{+}$: molecular ion.

prior to slaughter, and were processed in an industrial facility for 34 months. They are the same as those used in the previous works by Narváez-Rivas et al. (2013a, 2013b). The stages and the number of days from the beginning of the processing were as follows: after slaughter, the hams were removed from the carcasses after $24 \mathrm{~h}$ of refrigerated storage at $1{ }^{\circ} \mathrm{C}$. Then they were placed in piles completely covered with marine salt alone (they were not in contact with each other) at a low temperature $\left(1.0^{\circ} \mathrm{C}\right)$ and high relative humidity (about $80 \%$ ) for 12 days. After being washed to remove salt from the surface, the hams were hung at $3.0^{\circ} \mathrm{C}$ with a relative humidity of $76 \%$ for 26 days, then at $4.0^{\circ} \mathrm{C}$ with a relative humidity of $70 \%$ for 5 days. Next, they were kept at $6.0{ }^{\circ} \mathrm{C}$ with a relative humidity of $70 \%$ for 34 days and after this, they were kept at $7.0^{\circ} \mathrm{C}$ with a relative humidity of $70 \%$ for 15 days. This post-salting period was completed by raising the temperature to $12{ }^{\circ} \mathrm{C}$ at a rate of $1{ }^{\circ} \mathrm{C}$ every 3 days with a relative humidity of $70 \%$, up to 95 days. Then, they were taken to a dryer at temperatures varying from 7 to $26{ }^{\circ} \mathrm{C}$ and a relative humidity ranging from $12 \%$ to $80 \%$ for 231 days. Next, the hams were left to mature during 689 days in a cellar at temperatures ranging from 7 to $25^{\circ} \mathrm{C}$ and $16-82 \%$ relative humidity. The environmental conditions (temperature and relative humidity) were recorded continuously throughout the whole period of maturing.
A sample of each ham (about $1 \mathrm{~g}$ ) was taken across the subcutaneous adipose tissue covering the Biceps femoris muscle, without touching it, using a cylindrical stainless steel tool which is especially designed for this purpose (Narváez-Rivas et al., 2007, 2008, 2013a), about once a month since the animal was slaughtered (raw sample) until the drycured process was finished (cured ham). Samples were stored at $-25^{\circ} \mathrm{C}$ until analysis was carried out the following day. Before analysis, the samples of subcutaneous fat coming from both hams of each animal were mixed and minced in order to increase the interface between this and the stripping gas during the concentration step.

\subsection{Isolation and concentration of volatile compounds}

The volatile compounds were isolated from $0.5 \mathrm{~g}$ of minced sample by the dynamic headspace technique and adsorbed on a Tenax trap, using a Purge and Trap (P\&T) Concentrator apparatus, Tekmar velocity XPT (Thousand Oaks, CA, USA), based on the method described by Narváez-Rivas et al. (2010b). The purge conditions were as follows: sample temperature, $45^{\circ} \mathrm{C}$; Tenax trap temperature, $35^{\circ} \mathrm{C}$; purge gas flow, $350 \mathrm{~mL} \cdot \mathrm{min}^{-1}$ of nitrogen; purge time: $14 \mathrm{~min}$.

After the purge time, the volatile compounds were desorbed by heating the Tenax trap at $225^{\circ} \mathrm{C}$ 
for $1 \mathrm{~min}$, and sending the purge gas through a transfer line $\left(\mathrm{kept}\right.$ at $150{ }^{\circ} \mathrm{C}$ ) into the chromatograph injector.

\subsection{Gas chromatography/mass spectrometry (GC/MS) analysis}

The GC-ion-trap-MS analyses (Narváez-Rivas et al., 2010b) were performed using a Varian 3800 gas chromatograph coupled to a Saturno 2000 ion trap mass spectrometer (Varian, Palo Alto, CA, USA). The system was equipped with a 1079 injector operating in full scan mode from 50 to $600 \mathrm{amu}$ at $1 \mathrm{scan} / \mathrm{sec}$ for the purpose of identification. The column used was a Supelcowax-10 (SUPELCO, Bellefonte, PA, USA) fused silica capillary column $(60 \mathrm{~m}$ long $\times 0.25 \mathrm{~mm}$ i.d. $\times 0.25 \mu \mathrm{m}$ film thickness). The GC conditions included hydrogen as carrier gas at $1.6 \mathrm{~mL} \mathrm{~min} \mathrm{~m}^{-1}$ in constant flow mode. The oven temperature was held at $40{ }^{\circ} \mathrm{C}$ for $14 \mathrm{~min}$ with a first rise to $91{ }^{\circ} \mathrm{C}$ at $1{ }^{\circ} \mathrm{C} \cdot \mathrm{min}^{-1}$, and secondly to $201{ }^{\circ} \mathrm{C}$ at $10{ }^{\circ} \mathrm{C} \mathrm{min}{ }^{-1}$, and then finally to $220^{\circ} \mathrm{C}$ at $5^{\circ} \mathrm{C} \cdot \mathrm{min}^{-1}$, where it was held for 20 min. The split injection mode was used at a ratio of 1:5. The injector temperature was kept at 250 ${ }^{\circ} \mathrm{C}$. The MS operating conditions were as follows: ion source and transfer line temperatures were 200 and $290{ }^{\circ} \mathrm{C}$, respectively; the electron energy was $70 \mathrm{eV}$ a resolution of 1 and the emission current $250 \mu \mathrm{A}$; dwell time and inter-channel delay were $0.08 \mathrm{~s}$ and $0.02 \mathrm{~s}$, respectively. For GC-ion trapMS, Varian MS Workstation version 6.3 software was used for data acquisition and processing of the results. The alcohols and esters present in the volatile fraction of the fat samples were identified by computer matching of their mass spectra with those from NIST (National Institute of Standards and Technology) and Wiley libraries and verified by standards purchased from Sigma-Aldrich and Fluka (S. Louis, MO).

\subsection{Quantitative analysis}

The peak area was used as the analytical signal. The quantification of individual volatile compounds was carried out using the isoamyl butyrate as internal standard, which was prepared in refined sunflower oil (143.407 $\mathrm{mg} \cdot \mathrm{kg}^{-1}$ of oil). An equal relative response factor for any species was assumed. Isoamyl butyrate was used as a reference to calculate the relative retention time because it appears in all samples with high intensity at a mean retention time of $29.52 \mathrm{~min}$.

Repeatability was checked by consecutive analyses of one sample 12 times and values were expressed as relative standard deviation ranging between 15.6 and $28.4 \%$. In order to study the recovery of the present method, a complementary experiment has been carried out. Recovery data were calculated comparing the results of an available standard added onto a blank subcutaneous fat matrix with those obtained from the direct analysis of standard, both analyzed in the same way. Six replicates were determined in each case. Recoveries for the analytes with available standards varied between 95 and $119 \%$.

\subsection{Statistical treatments}

In order to determine whether significant differences were due to the effect of the dry-curing process, main effect analysis of variance (ANOVA) was performed according to the general linear model procedure (GLM).

The volatile alcohols and esters identified were considered as variables. In order to discover possible tendencies in the sample distribution according to their curing stage (post-salting, drying and cellar) as well as the discriminant power of the variables, the principal component analysis PCA was applied as a visualization technique. To obtain a suitable classification model, a linear discriminant analysis LDA was carried out. LDA is a supervised classificatory technique and widely recognized as an excellent tool to obtain vectors showing the maximum resolution among categories. A reduction in the number of variables used to construct the classification models was obtained with the LDA. The data were examined using the statistical package STATISTICA 8.0 from Statsoft (Tulsa, OK, USA).

\section{RESULTS AND DISCUSSION}

\subsection{Purge and Trap GC-MS analysis}

A total of fifteen alcohols and five esters were identified in the volatile fraction during the ripening of dry-cured Iberian ham using P\&T-GC-MS. The tentative assignment of the chromatographic peaks was completed by comparing the spectra with those from NIST and Wiley libraries and verified by standards when these were available. This is a complementary study of other previous ones (NarváezRivas et al., 2013a, 2013b, 2014).

The volatile components of the samples were separated using a high polarity column and the conditions of the purge and trap system and GCMS were previously described (Narváez-Rivas et al., 2010a). Under the conditions used in the purge step no degradation of the matrix sample was observed for any kind of compound. Figure 1 shows a chromatogram of the volatile fraction of the subcutaneous fat from Iberian ham. The relative retention time, molecular ion and base peak of the corresponding peaks are included in Table 1. Several alcohols and esters are present in this volatile fraction. 
(a)

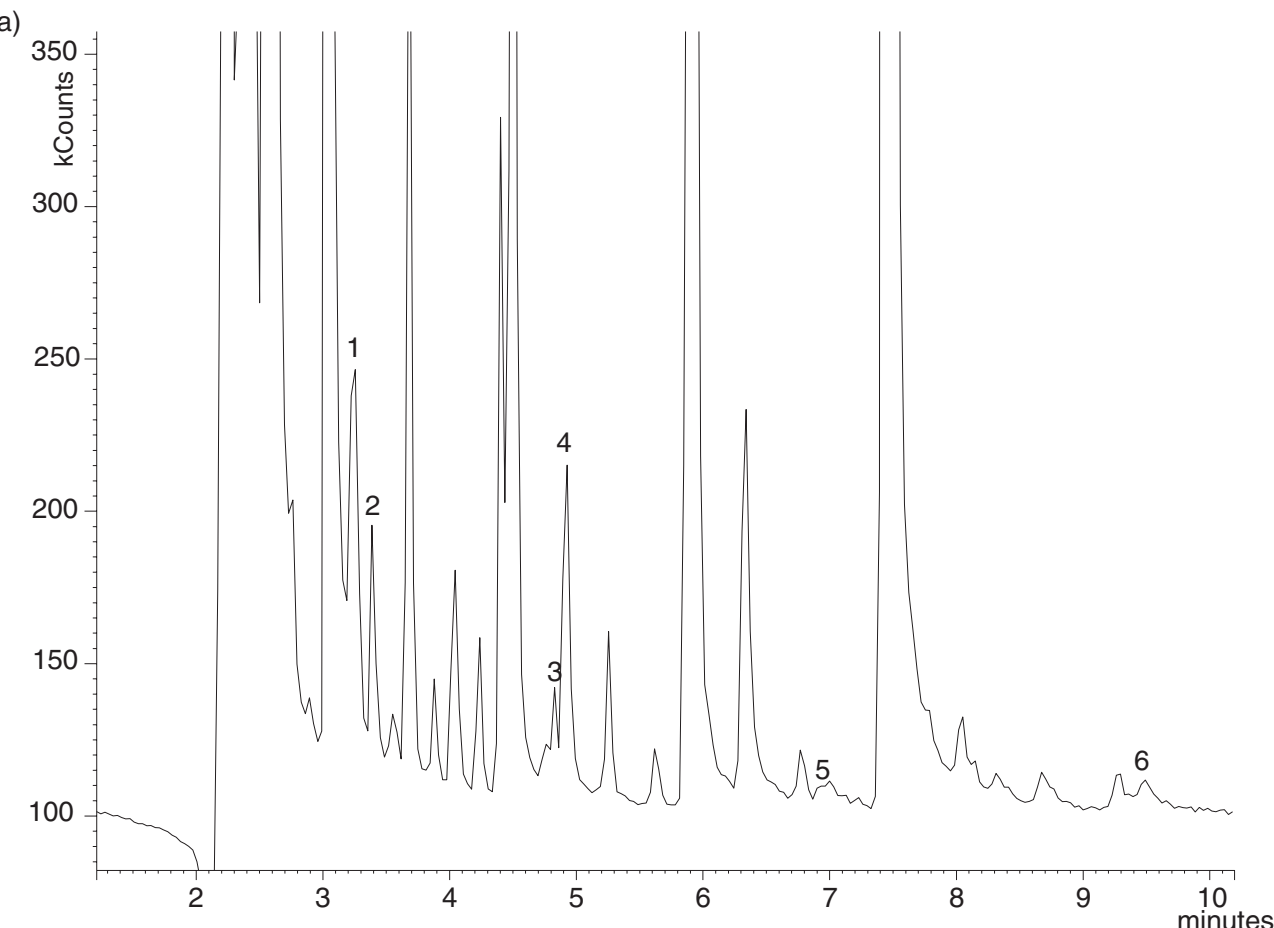

(b)

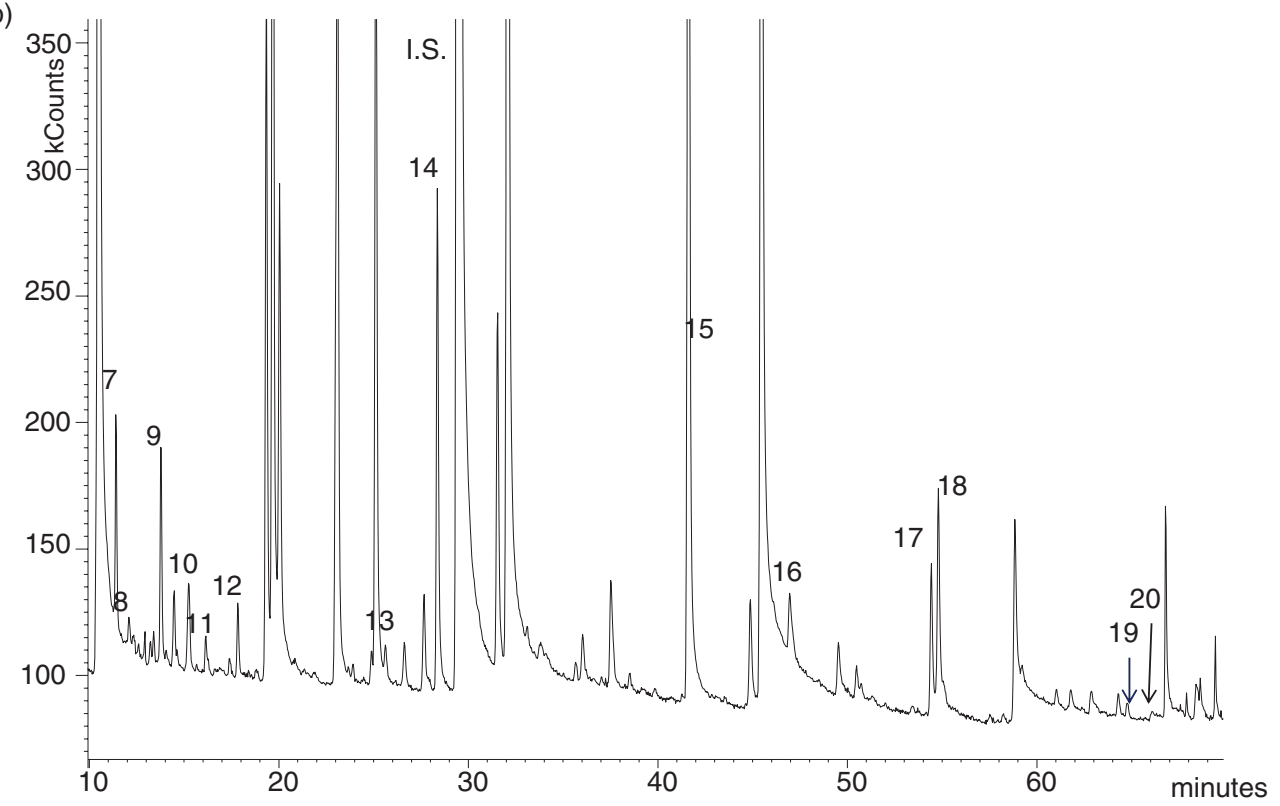

FIGURE 1. GC-Ion-Trap-MS Chromatogram from 0.0 to 80.0 minutes in full scan mode of the volatile compound profile of the subcutaneous fat from the Iberian ham sample. For peak identification see Table 1.

\subsection{Volatile alcohol profile in raw and dry-cured ham}

The alcohols as a group are important flavoring materials and are extensively found throughout nature. All contain a hydroxyl group, which largely determines their characteristics (Reineccius, 2006).

Alcohols of lower molecular weight have a sweet, spirituous odor that intensifies up the series to C9, which has an unpleasant oil-note. With increasing molecular weight, the pleasant odor is progressively replaced by a fatty and irritating odor characteristic. The higher alcohols are waxy solids having almost no odor. Unsaturated short chain alcohols, in which the double bound is close to the hydroxyl group, have a harsh, penetrating and irritating odor. However, mid-chain-length, 
unsaturated alcohols such as cis-3-hexenol are very important contributors to the "green" note. 1-Octene-3-ol is characteristic of mushrooms ( $\mathrm{La}$ Guerche, 2006). The aromatic alcohols are mostly pleasant and have well-rounded odor profiles. The substitution of two or more hydroxyl groups removes the odorous character of the compound in both the aliphatic and aromatic series (e.g., glycerol) (Reineccius, 2006).

The terpenoid alcohols represent a very distinct and important group of flavoring compounds found widely in essential oils (e.g., geraniol which occurs in rose oil has a characteristic rose-like smell). Aromatic alcohols in which the hydroxyl group is in the side chain have relatively weak but usually pleasant odor characters (Reineccius, 2006). However, this kind of alcohols was not found in the samples of the present study.

Fifteen volatile alcohols have been found in the subcutaneous fat from Iberian ham in this work, as shown in Table 1. In the literature (Narváez-Rivas et al., 2012), different odors have been assigned to ethanol (sweet), 2-propanol (buttery, dry), 1-pentanol (pungent, strong, balsamic, somewhat sweet), 1-hexanol (fruity, green), 1-octen-3-ol (mushroom, earthy, dusty, rust-like), 1-octanol (fatty, strong, acidic) and 1-nonanol (fatty, green) in Iberian ham. All the volatile alcohols detected in this work have been previously identified by other authors in Iberian ham, except 3-buten-2-ol, 5-methyl-3-hexanol and 2-isononanol. However, 2-methyl-3-hexanol and 3-methyl-3-hexanol were described earlier. It is logical that 3-buten-2-ol has not been identified in these samples before, since this alcohol is detected during processing but not in raw or dry-cured ham (see Table 2).

In raw and dry-cured samples, 3-buten-2-ol, 2-methyl-2-pentanol and 1-nonanol were not present, but these were detected during processing (Figures 2 and 3). In raw fat, the only alcohols found were ethanol, 2-propanol, 1-metoxy-2-propanol, 5-methyl-3- hexanol, 3-methyl-3-pentanol and 1-pentanol, but they were at very low concentrations $\left(0.01,0.03,0.43,0.01\right.$ and $0.03 \mathrm{mg} \cdot \mathrm{kg}^{-1}$ of fat, respectively) (Table 2). So, the most abundant volatile alcohol in the raw subcutaneous fat was 1-metoxy-2-propanol, while in dry-cured samples, 1-hexanol presented the highest concentration (Table 2). Andrade et al. (2009) reported that yeast belonging to "Los Pedroches industry" are responsible for the generation of ethanol and 2-methyl2-pentanol. It has been found that 1-heptanol and 1-octanol come from the oxidation of oleic acid, whereas 1-pentanol and 1-octen-3-ol are products of linoleic oxidation (Frankel, 1982).

As can be observed in Table 2, 3-buten-2-ol, 2-methyl-2-pentanol, 3-methyl-3-pentanol and 1-nonanol did not show significant differences with the dry-curing process while the other
TABLE 2. Effect of the dry-curing process on the volatile alcohol and ester amounts ( $\mathrm{mg} \cdot \mathrm{kg}^{-1}$ of fat)

\begin{tabular}{|c|c|c|}
\hline & \multicolumn{2}{|c|}{$\mathrm{mg} \cdot \mathrm{kg}^{-1}$ of fat } \\
\hline & $\begin{array}{c}\text { raw } \\
(n=5)\end{array}$ & $\begin{array}{c}\text { dry-cured } \\
(n=5)\end{array}$ \\
\hline \multicolumn{3}{|l|}{ Volatile alcohols } \\
\hline ethanol $^{\mathrm{b}}$ & $0.01 \pm 0.00$ & $0.14 \pm 0.09$ \\
\hline 1-pentanol ${ }^{\mathrm{c}}$ & $0.03 \pm 0.01$ & $0.42 \pm 0.14$ \\
\hline 1-hexanol ${ }^{\mathrm{c}}$ & $0.00 \pm 0.00$ & $1.46 \pm 0.48$ \\
\hline 1-heptanol ${ }^{\mathrm{c}}$ & $0.00 \pm 0.00$ & $0.22 \pm 0.09$ \\
\hline 1-octanol ${ }^{\mathrm{c}}$ & $0.00 \pm 0.00$ & $0.07 \pm 0.03$ \\
\hline 1-nonanol & $0.00 \pm 0.00$ & $0.00 \pm 0.00$ \\
\hline 2-propanol ${ }^{\mathrm{a}}$ & $0.03 \pm 0.01$ & $0.60 \pm 0.43$ \\
\hline 2-isononanol ${ }^{\mathrm{c}}$ & $0.00 \pm 0.00$ & $0.25 \pm 0.09$ \\
\hline 2-methyl-2-pentanol & $0.00 \pm 0.00$ & $0.00 \pm 0.00$ \\
\hline 3-methyl-3-pentanol & $0.02 \pm 0.02$ & $0.00 \pm 0.00$ \\
\hline 5-methyl-3-hexanol ${ }^{\mathrm{b}}$ & $0.01 \pm 0.01$ & $0.06 \pm 0.04$ \\
\hline 1-penten-3-ol ${ }^{\mathrm{b}}$ & $0.00 \pm 0.00$ & $0.08 \pm 0.05$ \\
\hline 1-octen-3-ol ${ }^{\mathrm{c}}$ & $0.00 \pm 0.00$ & $0.26 \pm 0.10$ \\
\hline 3-buten-2-ol & $0.00 \pm 0.00$ & $0.00 \pm 0.00$ \\
\hline 1-metoxy-2-propanol ${ }^{\mathrm{b}}$ & $0.43 \pm 0.31$ & $0.23 \pm 0.05$ \\
\hline Total alcohols ${ }^{c}$ & $0.53 \pm 0.28$ & $3.61 \pm 1.37$ \\
\hline \multicolumn{3}{|l|}{ Volatile esters } \\
\hline methyl ester 2-propenoic acid ${ }^{\mathrm{b}}$ & $0.02 \pm 0.01$ & $0.00 \pm 0.00$ \\
\hline ethyl ester pentanoic acid & $0.00 \pm 0.00$ & $0.00 \pm 0.00$ \\
\hline ethyl ester hexanoic acid ${ }^{b}$ & $0.00 \pm 0.00$ & $0.08 \pm 0.04$ \\
\hline 2-propenyl ester acetic acid ${ }^{\mathrm{d}}$ & $0.03 \pm 0.01$ & $0.42 \pm 0.10$ \\
\hline butyl ester formic acid & $0.00 \pm 0.00$ & $0.00 \pm 0.00$ \\
\hline Total esters $^{\mathrm{b}}$ & $0.06 \pm 0.01$ & $0.42 \pm 0.23$ \\
\hline
\end{tabular}

Data are the means \pm standard deviation. Different letters indicate significant differences between raw and dry-cured data (a for $\mathrm{p}<0.05$, b for $\mathrm{p}<0.01$, and $\mathrm{c}$ for $\mathrm{p}<0.001$, and $\mathrm{d}$ for $\mathrm{p}<0.00001)$.

volatile alcohols and their total amounts were significantly higher in the subcutaneous fat from Iberian dry-cured hams, except the 1-metoxy2-propanol, which decreased significantly with processing. The evolution of these compounds during the curing process of Iberian ham has not been studied before by other authors. Therefore, the curing process of Parma ham (Bolzoni et al., 1996) did not produce significant changes in percentages of 1-penten-3-ol, 1-pentanol and 1-hexanol, but significantly decreased the percentage of 1-octen-3-ol. At the same time, the amounts of 1-penten-3-ol, n-hexanol and 1-octen-3-ol did not show significant differences with processing in that type of ham, while ethanol and n-pentanol significantly increased and 2-propanol decreased (Hinrichsen and Pedersen, 1995). In Serrano ham (Pérez-Juan et al., 2006), 2-propanol and 1-pentanol increased with the dry-curing process and 

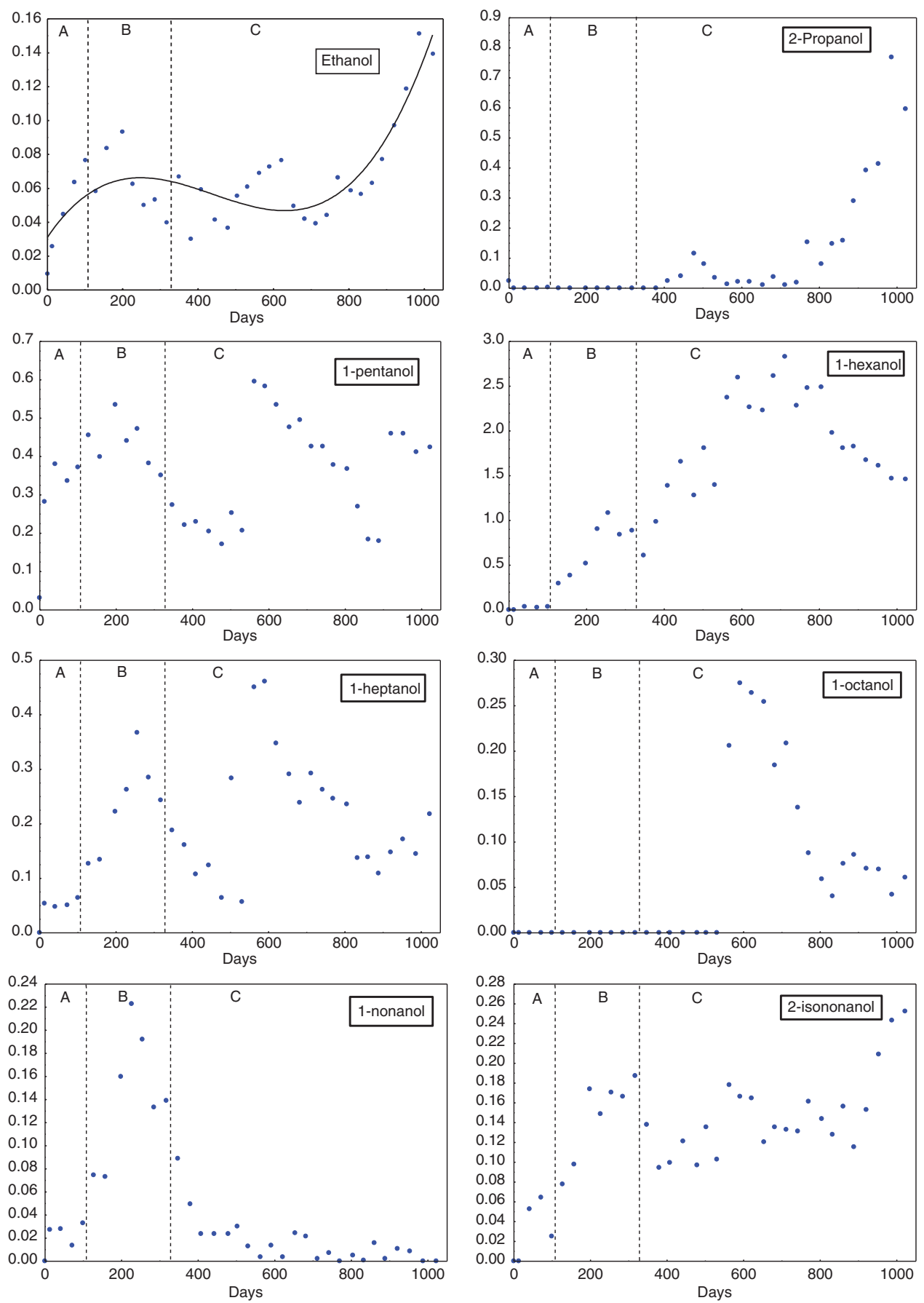

FIGURE 2. Evolution of different volatile linear alcohol amounts and 2-isononanol ( $\mathrm{mg}^{\circ} \mathrm{kg}^{-1}$ of fat; y axis) vs time of dry-cured (in days; $\mathrm{x}$ axis). (A): Post-salting period; (B): drying period; (C): Cellar period. The values represent the means of 5 replicates.

ethanol decreased. Huan et al. (2005) reported that the percentages of ethanol, 1-pentanol, 1-hexanol and 1-heptanol decreased during the dry-cured processing of Chinese Jinhua ham, while the percentages of 1-octanol, 1-octen-3-ol and 1-nonanol were significantly higher in drycured samples.

\subsection{Volatile ester profile in raw and dry-cured ham}

Esters are formed by the reaction of alcohols or phenols with acids and their derivatives. These compounds have a wide range of odors and flavoring effects, and are widely distributed in the essential oils and in some instances represent their major 

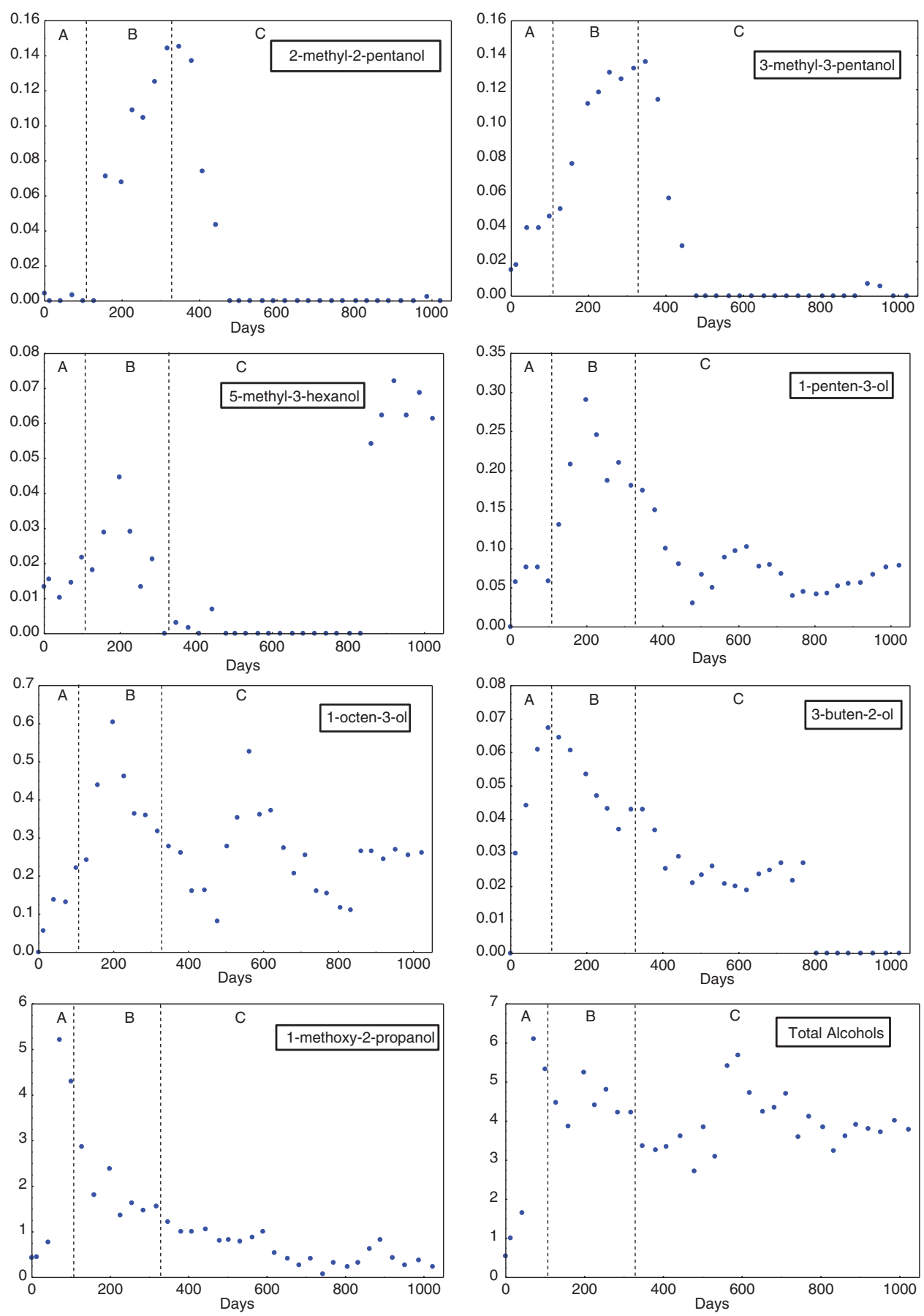

FIGURE 3. Evolution of different volatile alcohol amounts and total amounts of alcohols ( $\mathrm{mg} \cdot \mathrm{kg}^{-1}$ of fat; $\mathrm{y}$ axis) vs time of drycured (in days; $x$ axis). (A): Post-salting period; (B): drying period; (C): Cellar period. The values represent the means of 5 replicates.

constituent (Reineccius, 2006). Although some general structural/sensory relationships can be found within this group, particularly overall, they are by no means sufficiently well defined to form the basis of a useful classification. From the broad similarities which exist between them, it is preferable to consider esters according to their acid constituent (e.g., acetates, butyrates, isobutyrates, benzoates, etc.) rather than on their alcohol or phenol radical (e.g., methyl, ethyl, benzyl, eugenyl, etc.), though this moiety does have an increasingly significant effect on the profile as it becomes larger and/or more unsaturated. The profiles of the constituent acids and alcohols have almost no sensory relationship with that 
of the resulting ester (Reineccius, 2006). In Iberian ham, the odors assigned to methyl ester 2-propenoic acid have been fruity, apple-like, strawberry-like and olive-oil-like (Narváez-Rivas et al., 2012).

In Table 2, the amounts of volatile esters $\left(\mathrm{mg} \cdot \mathrm{kg}^{-1}\right.$ of fat) found in the subcutaneous fat from raw and dry-cured Iberian ham are shown. In raw fat, 2-propenyl ester acetic acid and methyl ester 2-propenoic acid were the only esters found, while in dry-cured samples, 2-propenyl ester acetic acid and ethyl ester hexanoic acid were detected. During processing, ethyl ester pentanoic acid and butyl ester formic acid were present in the fat, but they are absent in raw and dry-cured samples. Processing significantly increases the amounts of 2-propenyl ester acetic acid ( $\mathrm{p}<0.00001)$, ethyl ester hexanoic acid ( $\mathrm{p}<$ $0.01)$ and total esters $(\mathrm{p}<0.01)$, but decreases the concentration of methyl ester 2-propenoic acid ( $p$ $<0.01$ ). In Parma and Chinese Jinhua hams, ethyl ester pentanoic acid and ethyl ester hexanoic acid did not show significant differences during processing (Hinrichsen and Pedersen, 1995; Huan et al., 2005), but the total ester content increased, which is in agreement with that observed in the present work. However, Pérez-Juan et al. (2006) found that ethyl ester pentanoic acid decreased with the dry-curing process in Serrano hams.

\subsection{Evolution of the volatile alcohol fraction during the dry-cured process}

The evolutions of volatile alcohols detected during dry-curing process of Iberian ham are shown in Figures 2 and 3. In Figure 2, the evolution of the amount of ethanol (as $\mathrm{mg} \cdot \mathrm{kg}^{-1}$ of fat) during processing can be observed. This alcohol exhibited a cubic trend whose equation is $[$ Ethanol] $=0.0311+0.0003 *$ Days $-9.1884 \mathrm{E}-$ $7 *(\text { Days })^{2}+6.9788 \mathrm{E}-10 *$ (Days) $)^{3}$, undergoing a first increase up to 199 days ( $0.09 \mathrm{mg} \cdot \mathrm{kg}^{-1}$ of fat) in the drying period, a subsequent slight decrease up to 712 days $\left(0.04 \mathrm{mg} \cdot \mathrm{kg}^{-1}\right.$ of fat $)$ and a final sharp increase reaching a concentration of $0.14 \mathrm{mg} \cdot \mathrm{kg}^{-1}$ of fat.

In raw ham, 2-propanol was in small amounts $\left(0.025 \mathrm{mg} \cdot \mathrm{kg}^{-1}\right.$ of fat $)$ and then, it was not detected until 408 days in the cellar period, showing an exponential increase up to the end of processing (Figure 2). An opposite behavior was manifested by 1-metoxy-2-propanol (Figure 3), which increased up to the day 72 in the post-salting stage reaching a maximum value of $5.22 \mathrm{mg} \cdot \mathrm{kg}^{-1}$ of fat, and subsequently suffered an exponential reduction until the end of the process.

In the post-salting period, the 2-methy-1-pentanol increased while it decreased during the drying and cellar periods up to 682 days (Figure 3). After that, this volatile alcohol increased, reaching a maximum concentration of $0.093 \mathrm{mg} \cdot \mathrm{kg}^{-1}$ of fat $(889$ days) and finally diminished up to $0.048 \mathrm{mg} \cdot \mathrm{kg}^{-1}$ of fat.
In the case of 3-buten-2-ol (Figure 3), which was not present in raw fat, an initial increase was observed during post-salting, with a subsequent drop up to day 770. Between 805 and 1022 days, this alcohol was not detected. Another alcohol that did not exist or was at very low levels in raw and drycured samples was 2-methyl-2-pentanol (Figure 3). This last compound was generated during the drying period while it experienced a reduction in the cellar period and was not detected from day 478 of the process.

At the beginning of the process, 5-methyl-3-hexanol (Figure 3), 3-methyl-3-pentanol (Figure 3) and 1-nonanol (Figure 2) showed similar behaviors. They initially increased during the post-salting and drying period (5-methyl-3-hexanol up to 199 days, 3-methyl-3- pentanol up to 348 days and 1-nonanol up to 227 days) and afterwards they went down until day 478 , when their quantities began to be nonexistent or very small. However, there was a difference in their behaviors in the last six months of the process. 5-methyl-3-hexanol had its highest concentrations in such months while 3-methyl- 3-pentanol and 1-nonanol had the lowest. Figure 3 shows the evolution of 1-penten-3-ol amounts as a function of the dry-curing time. This showed a similar trend to 5- methyl-3-hexanol up to day 478. From here, the concentration of 1-penten-3-ol slightly increased up to day 620 and from 742 to 1022 days, and mildly decreased from 620 to 742 days.

Curios behavior is observed for 1-pentanol (Figure 2), 1-octen-3-ol (Figure 3) and 1-heptanol (Figure 2). These alcohols were lost during the second and third periods when the hams sweat (high temperatures), but not during the first of these periods (in post-salting) when they even increased. This last fact could be due to an intense hydrolysis of glycerides and the formation of these alcohols may be higher than their loss.

In Figure 2, the evolution of 1-hexanol can be observed. In the post-salting stage, this alcohol remained constant, but increased in the subsequent periods up to 712 days $\left(2.75 \mathrm{mg} \cdot \mathrm{kg}^{-1}\right.$ of fat $)$. Then, it experienced a drop until the end of process (1.46 $\mathrm{mg} \cdot \mathrm{kg}^{-1}$ of fat).

During the post-salting and drying periods and between 408 and 1022 days, 2-isononanol increased, showing the highest concentration at the end of processing $\left(0.25 \mathrm{mg} \cdot \mathrm{kg}^{-1}\right.$ of fat $)$. At the beginning of the cellar period (between 317 to 380 days), this compound decreased from 0.19 to $0.095 \mathrm{mg} \cdot \mathrm{kg}^{-1}$ of fat.

The linear alcohol 1-octanol (Figure 2) presented an opposite behavior to 2-methyl-2-pentanol (Figure 3) and 3-methyl-3-pentanol (Figure 3), and was not detected during post-salting, drying or at the beginning of the cellar period. Between 531 and 590 days, this sharply increased from 0 to $0.27 \mathrm{mg}$ $\mathrm{kg}^{-1}$ of fat, which coincided with high temperatures $\left(20-22{ }^{\circ} \mathrm{C}\right)$ and the end of the second period of 
sweating. Then, this decreased up to $0.04 \mathrm{mg} \cdot \mathrm{kg}^{-1}$ of fat (805 days) and subsequently underwent a slight increase, remaining then roughly constant until the end of processing.

Finally, total alcohol amounts (see Figure 3) showed a mix of all trends previously described. So, it had an initial increase up to 72 days (post-salting period) from 0.53 to $6.15 \mathrm{mg} \cdot \mathrm{kg}^{-1}$ of fat and a subsequent decrease up to 478 days (in cellar) (2.75 $\mathrm{mg} \cdot \mathrm{kg}^{-1}$ of fat). These low values coincide with the second sweating. Then, in the cellar period, this increased again up to $5.70 \mathrm{mg} \cdot \mathrm{kg}^{-1}$ of fat (590 days) and had other drop until the end of the process (3.61 $\mathrm{mg} \cdot \mathrm{kg}^{-1}$ of fat). As an overview, the amount of volatile alcohols increased in dry-cured Iberian ham. However, in the case of Chinese Jinhua (Huan et al., 2005) hams, the concentrations of volatile alcohols decreased during processing.
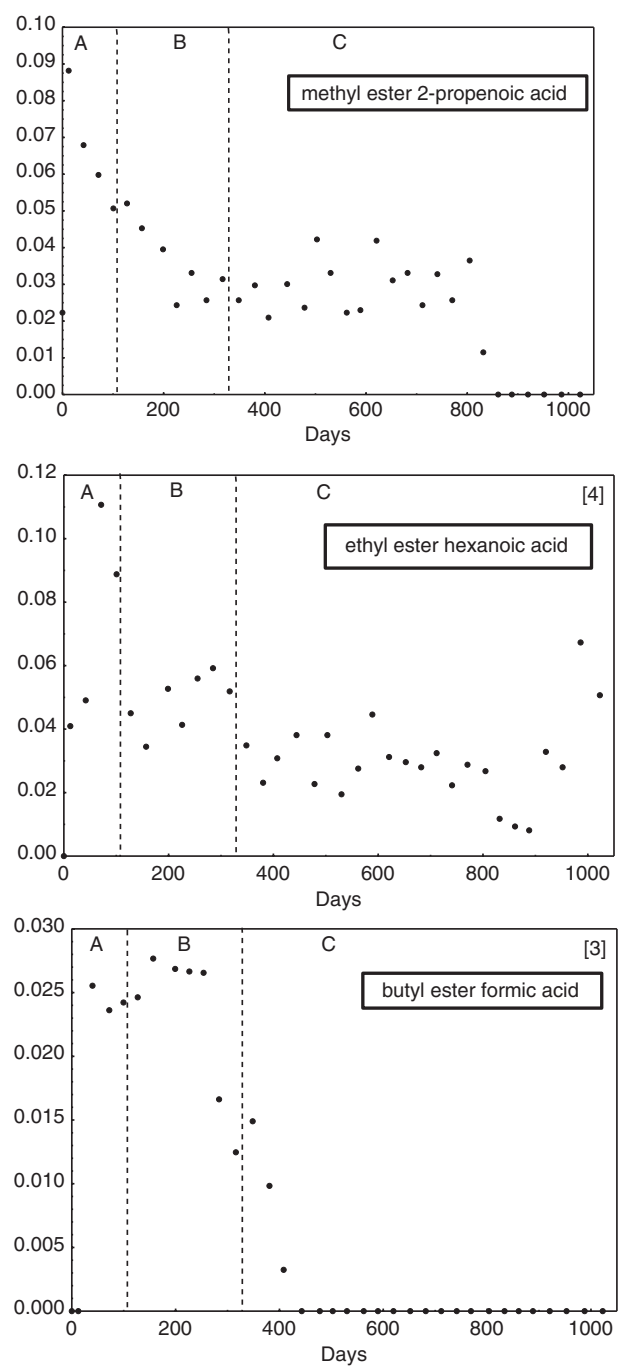

\subsection{Evolution of the volatile ester fraction during the dry-cured process}

As mentioned above, five esters have been detected in the subcutaneous fat from Iberian ham during processing in this work. Their evolutions are shown in Figure 4. Ethyl ester pentanoic acid and butyl ester formic acid are not present in raw and dry-cured samples, but they have been detected during the process. Ethyl ester pentanoic ester was found between 12 and 199 days, undergoing an increase during post-salting of up to $0.062 \mathrm{mg} \cdot \mathrm{kg}^{-1}$ of fat and a subsequent drop to later disappear. Butyl ester formic acid had a parallel behavior to ethyl ester pentanoic acid, showing a marked increase between 0 and 158 days, but then remained constant and subsequently underwent a sharp decrease to finally vanish.
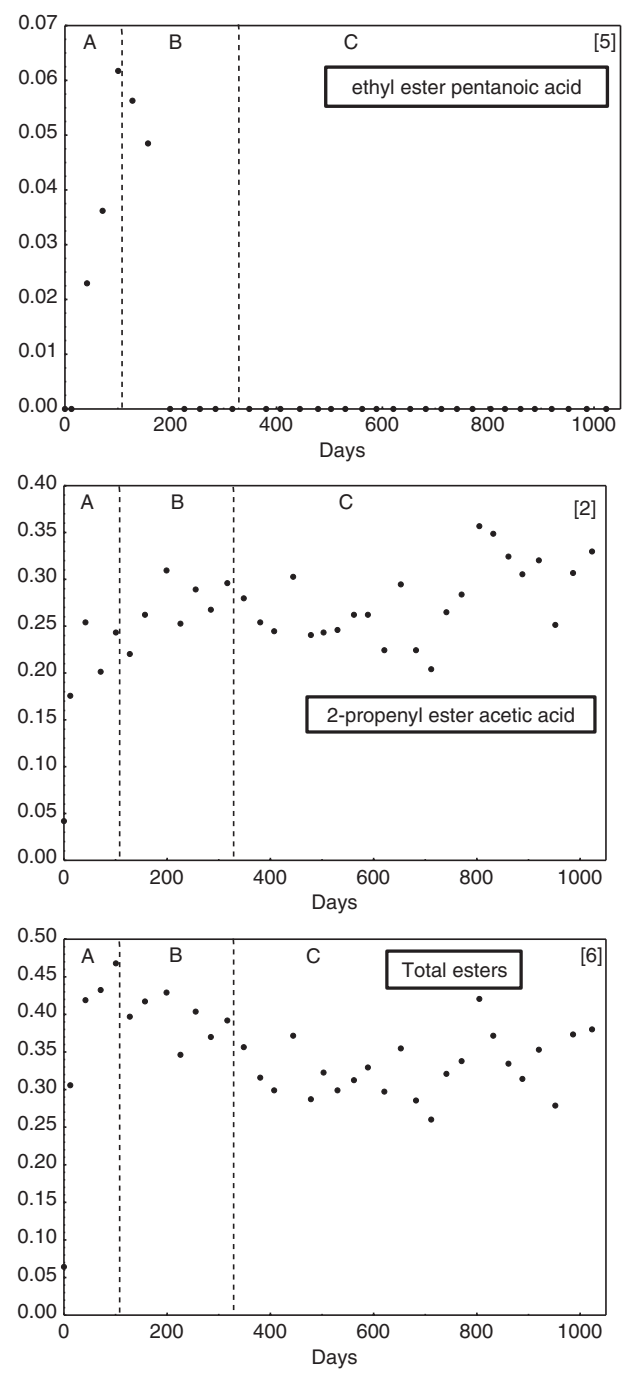

FIGURE 4. Evolution of different volatile ester amounts and their total amounts ( $\mathrm{mg}^{\circ} \mathrm{kg}^{-1}$ of fat; $\mathrm{y}$ axis) vs time of dry-cured (in days; $x$ axis). (A): Post-salting period; (B): drying period; (C): Cellar period. The values represent the means of 5 replicates. 
2-propenyl ester acetic acid showed a general increase during processing, and this is marked between 0 and 41 days (from 0.03 to $0.25 \mathrm{mg} \cdot \mathrm{kg}^{-1}$ of fat). In cellar, some decreases were observed, which coincided with increases in the sweaty fat. On the other hand, methyl ester 2-propenoic acid underwent a sharp increase in the salting period (between
0 and 12 days), but then decreased until the end of the drying period. In cellar, this alcohol remained more or less constant up to 805 days and subsequently decreased to disappear at day 861 until the end of the process.

Ethyl ester hexanoic acid presented an increase at the beginning of the process up to 72 days (in

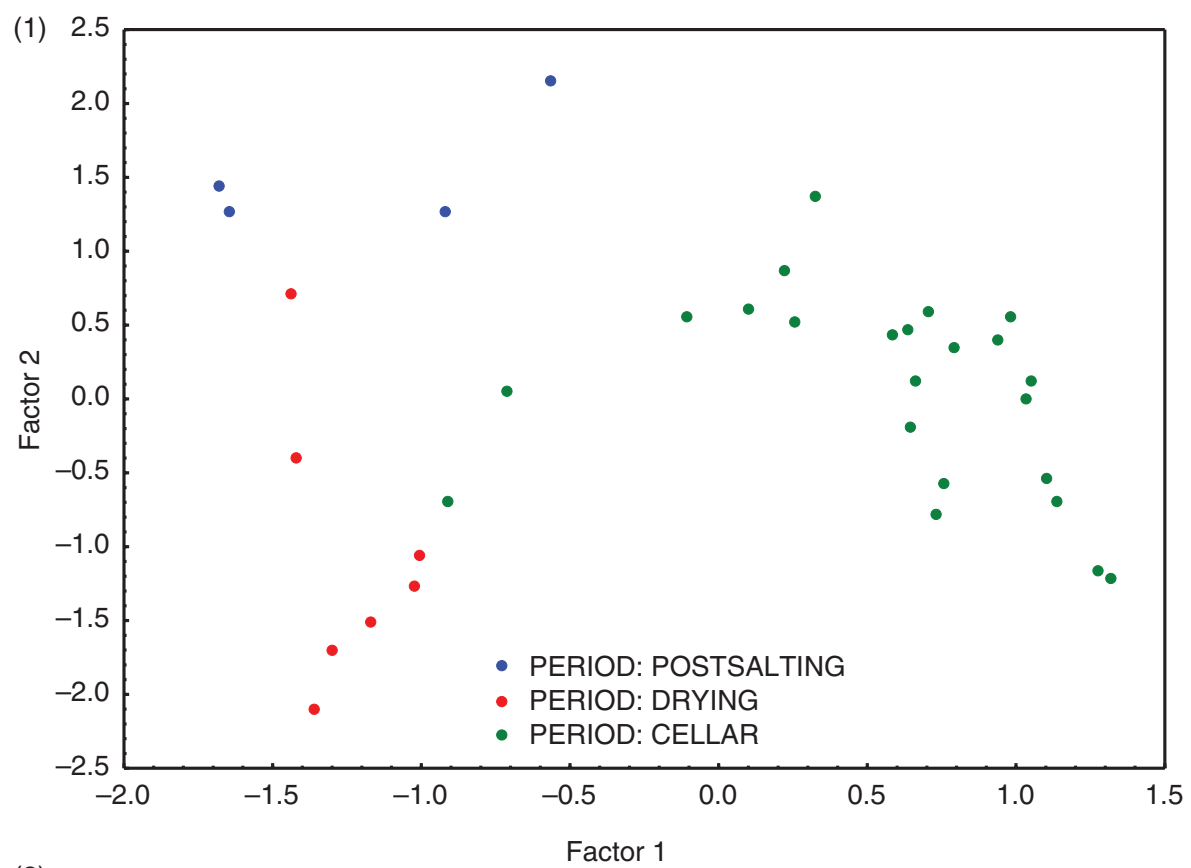

(2)

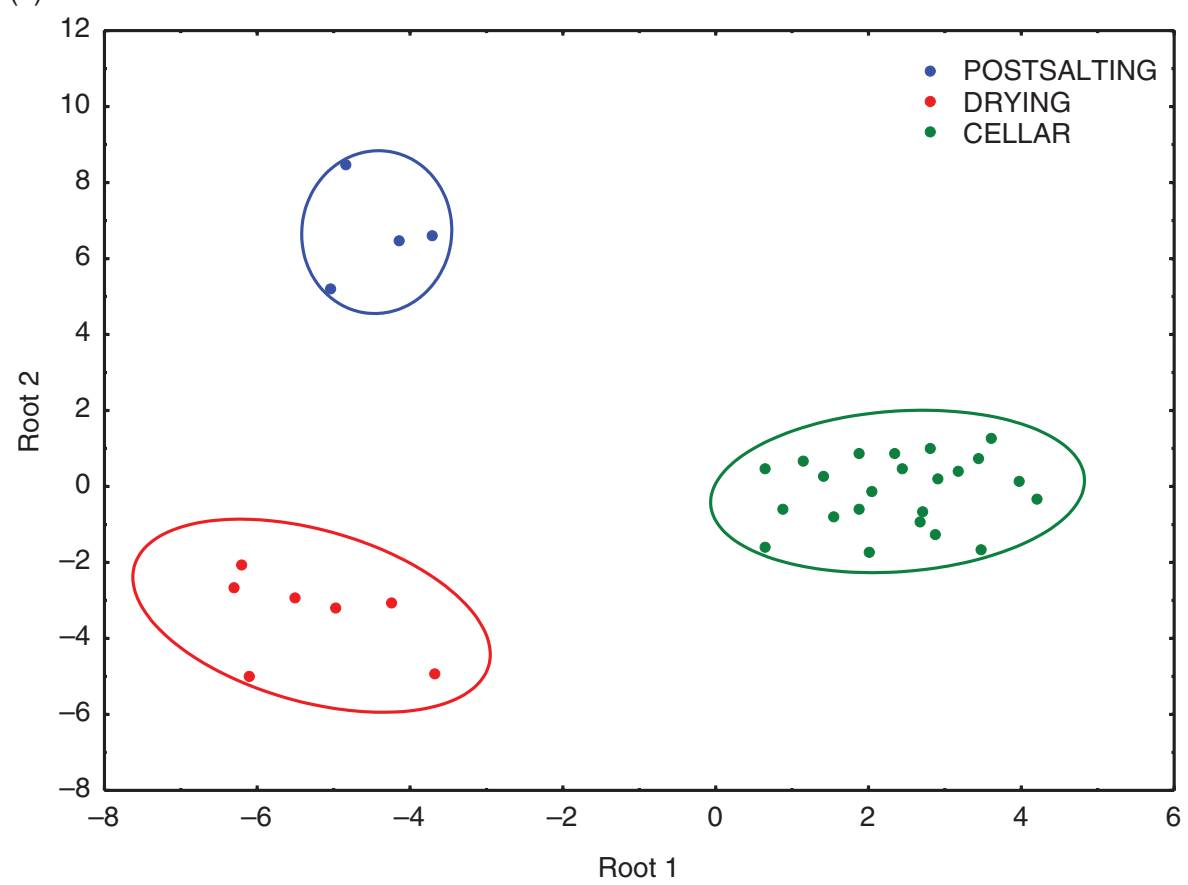

FIgURE 5. (1) Distribution of ham samples in the plane of the first two PCs, the variance is $36.16 \%$ for PC1 and $20.93 \%$ for PC2. (2) Scatter plot of the samples in the plane of the obtained discriminant functions vs time of dry-cured (in days). (A): Post-salting period; (B): drying period; (C): cellar period. 
the post-salting period), then a subsequent general decrease up to 889 days and a final increase (from 0.007 to $0.08 \mathrm{mg} \cdot \mathrm{kg}^{-1}$ of fat). The lowest concentrations that this alcohol reached in cellar, concurs with high temperatures and with periods when the hams sweat.

Since that all esters experienced an increase during post-salting (Figure 4). It is logical that their total amount showed the same trend (from 0.06 to $0.47 \mathrm{mg} \cdot \mathrm{kg}^{-1}$ of fat). In the drying period, although the major ester increased (2-propenyl ester acetic acid), all others decreased and as a consequence the total amount of ester decreased during such period. Finally, it can be observed that the total amount of these compounds follows the same trend as 2-propenyl ester acetic acid in cellar, and because of this it is the main ester and the others disappeared or were at much lower levels.

In Parma ham, Bolzoni et al. (1996) studied the changes in the aromatic profile in order to identify distinctive signals for different maturing periods (6, 9, 12 months), finding that methyl esters, carbonyl compounds and alcohols were the most relevant signals and that the greatest discriminating power was attributed to components such as ethyl esters and alcohols like 1-propanol, 1-butoxy-2-propanol and 2-butanol. In another study about this ham (Hinrichsen and Pedersen, 1995), flavor formation was divided into two phases: the first one (salting, drying and ripening) characterized by autoxidation and the second one (ripening and post-ripening) by secondary metabolism of microorganisms, particularly amino acid catabolism, in which methylbranched aldehydes, secondary alcohols, methyl ketones, ethyl esters and dimethyl trisulphide were generated (Hinrichsen and Pedersen, 1995). Regarding the Celtic ham, esters are the principal compounds of its smell. The development of esters consists of a slight decrease from the post-salting term until the cellar term, when its levels are highly increased. On the contrary, the amount of alcohols is quite high during the post-salting and drying periods to decrease to minimum values during ripening in the cellar (Bermúdez et al., 2015). These results are different from those belonging to Iberian dry-cured ham, in which we can notice only one small decrease in the amount of alcohols from the post-salting term until the end of the process, while the amount of esters is constant all along.

\subsection{Prediction of the curing time}

The principal component analysis (PCA) was applied to the data set to obtain linear combinations of the variables. The first principal component (PC1) expressed the largest variability and each successive PC represents as much of the residual variability as possible. Two-dimensional plots of the PCs can be used to reveal the internal structure of the data and visualize the data trends (Jolliffe, 2002). In this case, the first two PCs obtained explained 36.16 and $20.93 \%$ of the original variance, respectively. Figure 5 shows the distribution of the samples in the plane defined by the first two PCs. It can be observed that the samples belonging to the different periods appear separated in this space, with $\mathrm{PC} 1$ being the most differentiating factor. The loadings of the variables in the two extracted PCs are shown in Table 3. As can be seen, PC1 is highly influenced by 1-hexanol. In the case of PC2, the most contributing variables are 2-isononanol and 1-octen-3-ol. Taking into account the information from Figure 5.1 and Table 3, as post-salting and drying stages are better differentiated from the cellar stage according to $\mathrm{PC} 1$, it could be concluded that the contents in 3-buten-2-ol, 3-methyl-3-pentanol, 1-hexanol and butyl ester formic acid present the highest variability during the process. This fact points out these variables to provide valuable information in order to monitor the ripening process. The same can be observed for 2-isononanol and 1-octen-3-ol, because the post-salting and drying stages presented the highest differences according to PC2. An overlapping can be observed because this is a continuous process, with the samples corresponding to the beginning of drying mixed with those of post-salting and the first of the cellar mixed with the samples of drying. This also happened in the case of volatile aldehydes and ketones and volatile

TABLE 3. Loadings of the variables in the two first PCs

\begin{tabular}{lrr}
\hline & PC 1 & \multicolumn{1}{c}{ PC 2 } \\
\hline ethanol & 0.321848 & -0.500659 \\
2-propanol & 0.599121 & -0.269387 \\
1-methoxy-2-propanol & -0.761512 & 0.106710 \\
3-buten-2-ol & -0.941866 & 0.073986 \\
2-methyl-2-pentanol & -0.575310 & -0.507377 \\
5-methyl-3-hexanol & 0.195883 & -0.402998 \\
3-methyl-3-pentanol & -0.782724 & -0.469595 \\
1-penten-3-ol & -0.660138 & -0.687126 \\
1-pentanol & 0.012872 & -0.476497 \\
1-hexanol & 0.820915 & -0.097883 \\
2-isononanol & 0.495750 & -0.794410 \\
1-octen-3-ol & -0.219312 & -0.765326 \\
1-heptanol & 0.225035 & -0.560583 \\
1-octanol & 0.569251 & -0.067851 \\
1-nonanol & -0.688645 & -0.575123 \\
2-propenyl ester acetic acid & 0.388386 & -0.460628 \\
methyl ester 2-propenoic acid & -0.646632 & 0.516674 \\
ethyl ester pentanoic acid & -0.589510 & 0.319180 \\
butyl ester formic acid & -0.904874 & -0.220728 \\
ethyl ester hexanoic acid & -0.576614 & -0.038115 \\
\hline
\end{tabular}


TABLE 4. Results of the stepwise discriminant function analysis considering the "dry-curing periods" as grouping factors and a priori classification probabilities are the same for all groups

\begin{tabular}{|c|c|c|c|c|c|}
\hline Compounds & $\begin{array}{c}\begin{array}{l}\text { Post-salting } \\
\mathrm{p}=\mathbf{0 . 3 3 3 3 3}\end{array} \\
\end{array}$ & $\begin{array}{c}\text { Drying } \\
\mathrm{p}=\mathbf{0 . 3 3 3 3 3}\end{array}$ & $\begin{array}{c}\text { Cellar } \\
\mathrm{p}=\mathbf{0 . 3 3 3 3 3}\end{array}$ & $\begin{array}{c}\text { F to remove } \\
(2.22)\end{array}$ & p-level \\
\hline butyl ester formic acid & 882.483 & -1045.55 & -748.585 & 4.38154 & 0.025022 \\
\hline 1-penten-3-ol & -115.134 & 134.21 & 7.493 & 2.89458 & 0.076563 \\
\hline methyl ester 2-propenoic acid & 1372.971 & 1156.51 & 544.190 & 10.46199 & 0.000641 \\
\hline 5-methyl-3-hexanol & 712.560 & 625.93 & 275.031 & 3.98502 & 0.033350 \\
\hline 1-nonanol & 153.076 & 500.00 & 154.228 & 8.12616 & 0.002277 \\
\hline ethyl ester pentanoic acid & 196.282 & 1617.89 & 473.250 & 11.51567 & 0.000378 \\
\hline ethyl ester hexanoic acid & 419.070 & -179.65 & -260.535 & 7.98403 & 0.002472 \\
\hline 2-isononanol & 156.507 & 523.43 & 318.047 & 6.25027 & 0.007089 \\
\hline ethanol & -264.887 & -519.15 & -112.270 & 2.85695 & 0.078882 \\
\hline 3-buten-2-ol & 29.900 & -43.18 & 435.053 & 1.11000 & 0.347323 \\
\hline Constant & -73.232 & -94.69 & -29.604 & & \\
\hline
\end{tabular}

hydrocarbons (Narváez-Rivas et al., 2014; 2015). In the industry, there is no objective criterion to move hams from one stage to another. This is one of the aims of this study.

To achieve an adequate classification model, linear discriminant analysis (LDA) was applied. The LDA was applied with the aim of grouping (Wilks' Lambda: 0.00440) (see Fig. 5.2). The two discriminant functions (Roots 1 and 2) were obtained using backward stepwise analysis retaining the ten variables shown in Table 4. The classification functions together with $F$ to remove $p$ values for each volatile compound selected are also shown in Table 4. A complete separation between the three periods was obtained (Fig. 5.2) as in the case of the volatile hydrocarbons and volatile aldehydes and ketones (Narváez-Rivas et al., 2014; 2015), indicating that the retained variables are potent descriptors to classify samples from these three dry-curing periods.

In summary, in this work, fifteen volatile alcohols and five esters have been identified and quantified by the purge and trap-GC-MS method during the dry-curing process (including post-salting, drying and cellar periods) of Iberian ham for the first time using the same pieces. During processing, 3-buten2-ol, 2-methyl-2-pentanol, 3-methyl-3-pentanol and 1 -nonanol did not show significant differences, while the other volatile alcohols and their total amounts were significantly higher in the subcutaneous fat from Iberian dry-cured hams, except 1-metoxy2-propanol, which decreased significantly with processing. Their origin is the lipid oxidation, and yeast belonging to "Los Pedroches industry", which is responsible for the generation of some of them like ethanol and 2-methyl-2-pentanol. During the drycuring process, ethyl ester pentanoic acid and butyl ester formic acid were present in fat, but they were absent in raw and dry-cured samples. Processing significantly increased the amounts of 2-propenyl ester acetic acid, ethyl ester hexanoic acid and total esters, but decreased the concentration of methyl ester 2-propenoic acid. LDA allowed a total differentiation between the three ripening periods using alcohol and ester compounds. This function of classification could be used in order to predict the curing time.

\section{ACKNOWLEDGEMENTS}

The authors are grateful to the Designated Origin "Los Pedroches" and IBESA for their collaboration and help. This study was supported by project P08-AGR-03498.

The present work is part of the doctoral thesis of the author: "Study of the lipid fraction and volatile compounds generated in the subcutaneous adipose tissue from Iberian ham during the dry-curing process". University of Sevilla. May. 2012.

\section{REFERENCES}

Andersen HJ, Oksbjerg N, Young JF, Therkildsen M. 2005. Feeding and meat quality- a future approach. Meat Sci. 70, 543-554. http://dx.doi.org/10.1016/j.meatsci.2004.07.015

Andrade MJ, Córdoba JJ, Sánchez B, Casado EM, Rodríguez M. 2009. Evaluation and selection of yeasts isolated from dry-cured Iberian ham by their volatile compound production. Food Chem. 113, 457-463. http://dx.doi.org/10.1016/j. foodchem.2008.07.080

Andrés AI, Cava R, Ventanas S, Muriel E, Ruiz J. 2007. Effect of salt content and processing conditions on volatile compounds formation throughout the ripening of Iberian ham. Europ. Food Res. Technol. 225, 677-684. http://dx.doi. org/10.1007/s00217-006-0465-z

Antequera T, López-Bote CJ, Córdoba JJ, García C, Asensio MA, Ventanas J, García-Regueiro JA, Díaz I. 1992. Lipid oxidative changes in the processing of Iberian pig hams. Food Chem. 45, 105-110. http://dx.doi. org/10.1016/0308-8146(92)90018-W

Bermúdez R, Franco D, Carballo J, Lorenzo JM. 2015. Influence of type of muscle on volatile compounds throughout the manufacture of Celta dry-cured ham. Food Sci. Technol. Int. 21, 581-592. 
Bolzoni L, Barbieri G, Virgili R. 1996. Changes in volatile compounds of Parma ham during maturation. Meat Sci. 43, 301-310. http://dx.doi.org/10.1016/S0309-1740(96)00002-2

Cava R, Ruiz J, Ventanas J, Antequera T. 1999. Effect of $\alpha$-tocopheryl acetate supplementation and the extensive feeding of pigs on the volatile aldehydes during the maturation of Iberian ham. Food Sci. Technol. Internat. 5, 235-241. http://dx.doi.org/10.1177/108201329900500306

Coutron-Gambotti C, Gandemer G. 1999. Lipolysis and oxidation in subcutaneous adipose tissue during dry-cured ham processing. Food Chem. 64, 95-101. http://dx.doi. org/10.1016/S0308-8146(98)00079-X

Dirinck P, Van Opstaele F, Vandendriessche F. 1997. Flavour differences between northern and southern European cured hams. Food Chem. 59, 511-521. http://dx.doi.org/10.1016/ S0308-8146(97)00012-5

Flores M, Grimm CC, Toldrá F, Spanier AM. 1997. Correlations of sensory and volatile compounds of Spanish "Serrano" Dry-Cured Ham as a function of two processing Times. J. Agric. Food Chem. 45, 2178-2186. http://dx.doi. org/10.1021/jf960862c

Hinrichsen LL, Pedersen SB. 1995. Relationship among Flavor, Volatile Compounds, Chemical Changes, and Microflora in Italian-Type Dry-Cured Ham during Processing. J. Agric. Food Chem. 43, 2932-2940. http://dx.doi.org/10.1021/ jf00059a030

Huan Y, Zhou G, Zhao G, Xu X, Peng Z. 2005. Changes in flavor compounds of dry-cured Chinese Jinhua ham during processing. Meat Sci. 71, 291-299. http://dx.doi.org/10.1016/j. meatsci.2005.03.025

Jurado A, García C, Timón ML, Carrapiso AI. 2007. Effect of ripening time and rearing system on amino acid-related flavour compounds of Iberian ham. Meat Sci. 75, 585-594. http://dx.doi.org/10.1016/j.meatsci.2006.09.006

La Guerche S, Dauphin B, Pons M, Blancard D. Darriet P. 2006. Characterization of Some Mushroom and Earthy OffOdors Microbially Induced by the Development of Rot on Grapes. J. Agric. Food Chem. 54, 9193-9200. http://dx.doi. org/10.1021/jf0615294

Lorenzo JM, Carballo J, Franco D. 2013. Effect of the inclusion of chestnut in the finishing diet on volatile compounds of dry-cured ham from Celta pig breed. J. Integrative Agric. 12, 2002-2012

Martín L, Timón ML, Petrón MJ, Ventanas J, Antequera T. 2000. Evolution of volatile aldehydes in Iberian ham matured under different processing conditions Meat Sci. 54, 333-337. http://dx.doi.org/10.1016/S0309-1740(99)00107-2

Narváez-Rivas M, Gallardo E, León-Camacho M. 2012. Analysis of volatile compounds from Iberian hams: a review. Grasas Aceites 63, 432-452. http://dx.doi.org/10.3989/gya.070112

Narváez-Rivas M, Gallardo E, León-Camacho M. 2013a. Changes in polar and non-polar lipid fractions of subcutaneous fat from Iberian ham during dry-curing process. Prediction of the curing time. Food Res. Int 54, 213-222. http://dx.doi.org/10.1016/j.foodres.2013.07.004

Narváez-Rivas M, Gallardo E, León-Camacho M. 2013b. The changes in gliceridic fractions of sweaty fat and weight loss during ripening time of Iberian dry-cured ham.
Food Res. Int. 54, 1657-1669. http://dx.doi.org/10.1016/j. foodres.2013.09.014

Narváez-Rivas M, Gallardo E, León-Camacho M. 2014. Chemical changes in volatile aldehydes and ketones from subcutaneous fat during ripening of Iberian dry-cured ham. Prediction of the curing time. Food Res. Internat 55, 381-390. http://dx.doi.org/10.1016/j.foodres.2013.11.029

Narváez-Rivas M, Gallardo, León-Camacho M. 2015. Evolution of volatile hydrocarbons from subcutaneous fat during ripening of Iberian dry-cured ham. A tool to differentiate between ripening periods of the process. Food Res. Int. 67, 299-307. http://dx.doi.org/10.1016/j.foodres.2014.11.031

Narváez-Rivas M, Gallardo E, Ríos JJ, León-Camacho M. 2010a. A tentative characterization of volatile compounds from Iberian Dry-Cured Ham according to different anatomical locations. A detailed study. Grasas Aceites 61, 369-377. http://dx.doi.org/10.3989/gya.020910

Narváez-Rivas M, Pablos F, Jurado JM, León-Camacho M. 2011. Authentication of fattening diet of Iberian pigs according to their volatile compounds profile from raw subcutaneous fat. Anal. Bioanal. Chem. 399, 2115-2122. http://dx.doi.org/10.1007/s00216-010-4387-z

Narváez-Rivas M, Vicario IM, Alcalde MJ, León-Camacho M. 2010b. Volatile hydrocarbon profile of Iberian dry-cured hams. A possible tool for authentication of hams according to the fattening diet. Talanta 81, 1224-1228. http:// dx.doi.org/10.1016/j.talanta.2010.02.013

Narváez-Rivas M, Vicario IM, Graciani Constante E, LeónCamacho M. 2007. Changes in the Concentrations of Free Fatty Acid, Monoacylglycerol, and Diacylglycerol in the Subcutaneous Fat of Iberian Ham during the Dry-Curing Process. J. Agric. Food Chem. 55, 10953-10961. http:// dx.doi.org/10.1021/jf071886u

Narváez-Rivas M, Vicario IM, Graciani Constante E, LeónCamacho M. 2008. Changes in the Fatty Acid and Triacylglycerol profiles in the Subcutaneous Fat of Iberian Ham during the Dry-Curing Process. J. Agric. Food Chem. 56, 7131-7137. http://dx.doi.org/10.1021/jf800990u

Pérez-Juan M, Flores M, Toldrá F. 2006. Generation of volatile flavour compounds as affected by the chemical composition of different dry-cured ham sections. Eur. Food Res. Technol. 222, 658-666. http://dx.doi.org/10.1007/ s00217-005-0196-6

Ramírez R, Cava R. 2007. Volatile profiles of Dry-Cured meat products from three different Iberian $\mathrm{X}$ Duroc genotypes. J. Agric. Food Chem. 55, 1923-1931. http://dx.doi. org/10.1021/jf0628101

Reineccius G. 2006. Off-flavors and taints in foods. In G. Reineccius (Ed.), Flavor Chemistry and Technology (pp. 161-200). Boca Raton, Florida: Taylor and Francis.

Ruiz J, Ventanas J, Cava R, Andrés A. García C. 1999. Volatile compounds of dry-cured Iberian ham as affected by the length of the curing process. Meat Sci. 52, 19-27. http:// dx.doi.org/10.1016/S0309-1740(98)00144-2

Sabio E, Vidal-Aragón MC, Bernalte MJ, Gata JL. 1998. Volatile compounds present in six types of dry-cured ham from south European countries. Food Chem. 61, 493-503. http://dx.doi.org/10.1016/S0308-8146(97)00079-4 